\title{
Laser treatment may enhance growth and resistance to fungal infection of hard wheat seeds
}

\author{
Yasemin Z.Rassam ${ }^{1}$ Firdaws A.Al .Mashhadani ${ }^{1}$ Amange F.Boya ${ }^{2}$ \\ 1(Food Technology Department, Collage of Agriculture/Salahaldine University,Iraq) \\ 2(Physics Department, Collage of Science/Salahadine University, Iraq.)
}

\begin{abstract}
The effect of Hard wheat (Triticum durum) seeds exposer to visible light with $\lambda=632 \mathrm{~nm}, 650 \mathrm{~nm}$ and 532nm produced from He-Ne,Diode and SHG Nd-YAG lasers respectively on germination, early growth and resistance to fungal infections had been studied under laboratory conditions. He-Ne \& diode laser enhanced the germination percentage of wheat cultivars after two days a maximum of $95 \%$ \& $93 \%$ after irradiation respectively for 5 minutes in respect to control, with the beginning to infection with fungus in both irradiated and non irradiated seeds, SHG Nd-YAG laser significantly enhanced the germination percentage of wheat after 3 days to reach maximum of $93 \%$ after irradiation. Seeds irradiated with SHG Nd-YAG laser, no fungi infection was recorded, while seeds irradiated by the two other types show highly infection especially after 3 days, and the petri plates which added to them antifungal agent show significant increase in infection with and without irradiation. From these results, we concluded that SHG Nd-YAG laser Irradiation could be an alternative method to control seed infection by fungi of hard wheat seeds.
\end{abstract}

Keywords: Laser radiation, hard wheat, fungal infection, generation, $S H G \mathrm{Nd}-Y A G$.

\section{Introduction:}

The growing need for ecological agricultural products together with the increased demand of crop materials for food production as well as for other branches of industry imposes the necessity for searching new, safer decisions for raising the agricultural production [1]. Sustainable agriculture is a management system for renewable natural resource for food production income and livelihood for present and future generations, maintaining and improving in comic productivity and the ecosystem [2].The last 50 years different chemical additives are used for fertilizing crops ,controlling pests and helping to develop highly successful farm system, ensuring an abundant and wholesome food supply as described by[3], but their application causes the contamination of raw materials for food production with toxins, decrease in plant resistance,plant yield and soil yielding capacity [2].The influence of physical factors as microwave and laser radiation are useful for plants enable to vegetate at higher energy level .It is based on the fact that physics methods increase the energy account by internal transformation of energy independent of their origin into electrical and increasing the electro potential of the biomembrane [4].The germination of seeds is dependent on both internal and external conditions, one of the most important external factors is light [5] Which plays critical role in plants photosynthesis, also the non-photosynthetic processes involving action of light ,like photo morphogenesis[6]. Laser irradiation is considered as a new branch in agriculture [7].the amazing characteristic of laser radiation, such as monochromatic, polarization, coherence and high density, can be used in all spheres of biology and plant growing [8].The changes that occur in the physiological state of seeds and plants can stimulate or inhibit their development and resistance to fungal disease , and depend closely on the laser radiation type ,its wavelength ,intensity and the duration of exposition [2][9][10]. Various authors in the world provide the possibility of accelerating the maturity of plants; increase their resistance to disease; influence alpha-amylase activity and the concentration of free radicals in the seeds of several plants using laser light [11][12][13][14][15][16] [17][18][19] .On the other hand many studies have proved that fungal pathogens of wheat cause about $10 \%$ yield loss worldwide [20]. A range of survey showed the impact of laser treatment on dynamics of germination and disease resistance for number of vegetables, and cereals, peas, wheat, radishes and corn [21][22][23] [24][25] , but it is necessary to run more experiments to determine its potential in controlling plant diseases of seed, especially fungi. This work aimed to study the effect of different laser irradiation and exposure time on germination, growth and resistant to fungal disease of hard wheat seeds.

\section{Materials and Methods}

The present experiment were carried out at the department of food biotechnology, college of agriculture, Salahalddine University., and laboratory analysis of seeds and seedlings at Erbil center of agriculture research, Erbil, Kurdistan regional government. Seeds were irradiated by different kind of laser at the department of physics, college of science, Salahalddin University, Erbil, during 3monthes period between March 2011 June 2011. 
2.1.Seed materials: Hard wheat (Triticum durum) seeds used in this work were supplied by the Erbil research center of agriculture. Four hundred seeds of uniform size were hand selected .The seeds were kept in dark for three weeks before the experiment to protect them from accidental exposure of light. No extra chemicals or physiological photosensitization was applied before irradiation.

2.2. Laser source and irradiation procedure: continuous laser irradiation at $\lambda=632.8 \mathrm{~nm}$ was obtained from He-Ne laser with total maximum output power of $1 \mathrm{~mW}$ and beam diameter $(2 \mathrm{~mm})$.Diode laser, $650 \mathrm{~nm}$ wavelength with $5 \mathrm{~mW}$ output power with beam diameter $2 \mathrm{~mm}$., and second harmonic Nd-YAG laser $532 \mathrm{~nm}$ wavelength and total output power $20 \mathrm{~mW}$, with beam diameter $2 \mathrm{~mm}$. The set up diagram is shown in Fig.1 the irradiation procedure of laser beam after expansion it and hit the wheat seeds.

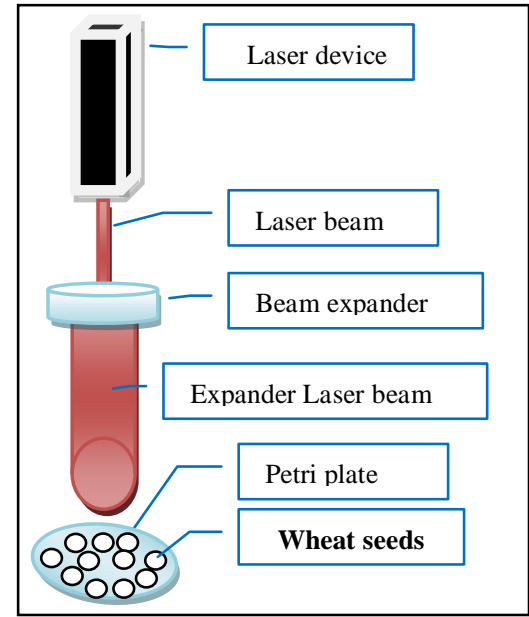

Fig.1 set up diagram shown irradiation procedure of laser beam

The seeds were divided into two groups. The first one was irradiated in dry conditions and other was irradiated in wet conditions .Each group was divided into five subgroups (10 seeds). The first is the control (no irradiation) and the rest were irradiated to 1, 5, 10, 15 minutes to He-Ne laser, another groups of seeds were irradiated with Diode laser and SHG Nd-YAG laser at the same conditions and classification. First group of seeds was irradiated without soaking (dry group ); the second one was irradiated after soaking in irrigation water for 24hours (wet seeds group). Both dry and wet groups were irradiated in two replicates.

2.3. Germination test: After the treatments, irradiated and control seeds were placed in $9 \mathrm{~cm}$ glass ,one of each group were supplemented with antifungal agent ,Petri dished lined with three layers of filter paper .Before the experiments, the Petri dishes were sterilized for three hours at $150 \mathrm{C}^{\circ}$. Constant temperature of 20-25 $\mathrm{C}^{\circ}$.The relative humidity in the Petri dish was near $100 \%$ as evidenced by vapor concentration on the lid .During the experiment filter papers were kept at an optimal humidity level by adding the fresh distilled water to the Petri dish when needed. Petri dishes were set out in a completely randomized design and the position of dishes were randomly changed at every count to minimize positional effect in the chamber.Tempreture readings were taken before each observation, and fluctuations of the mean temperature ranged up to $1 \mathrm{C}^{\circ}$. Seeds were germinated in dark, except when they were scored .Counts for the number of seeds that had germinated was done after 4,7 and 10 days .After the tenth day the percentage of seeds germinated normally and abnormally as well as the seed that had not germinated at all were calculated. breaking seed coat, emergence of the radical with length equal to the seed length is the criterion for germination. Seeds were checked for the presence of fungus .counting procedure takes 3-6min , dishes were returned to chamber. The results of the experiments were analyzed statically to find the difference between each laser treatment and control using Student t-test.

\section{Results:}

The percentage of seed germination normally and abnormally as well as of no germinated seeds after He-Ne and diode laser treatment in dry and wet conditions were shown in Table $1 \& 2$. 
Laser treatment may enhance growth and resistance to fungal infection of hard wheat seeds

\begin{tabular}{|c|c|c|c|c|c|c|}
\hline \multicolumn{6}{|c|}{$\begin{array}{c}\text { Table 1 } \\
\text { Influence of He-Ne laser treatment on seed } \\
\text { germination }\end{array}$} \\
\hline \multicolumn{3}{|c|}{ Treatments } & \multicolumn{5}{c|}{$\%$ of seeds } \\
\hline & $\begin{array}{c}\text { Germinated } \\
\text { normally }\end{array}$ & $\begin{array}{c}\text { Germinated } \\
\text { abnormally }\end{array}$ & $\begin{array}{c}\text { Non } \\
\text { germinated } \\
\text { seeds }\end{array}$ \\
\hline & dry & wet & dry & wet & dry & wet \\
\hline Control & 70 & 80 & 15 & 16 & 15 & 4 \\
\hline H1 & 85 & 93 & 5 & 2 & 10 & 5 \\
\hline H2 & 83 & 95 & 4 & 2 & 13 & 3 \\
\hline H3 & 70 & 83 & 10 & 10 & 20 & 7 \\
\hline H4 & 60 & 65 & 5 & 10 & 35 & 25 \\
\hline
\end{tabular}

\begin{tabular}{|c|c|c|c|c|c|c|}
\hline \multicolumn{7}{|c|}{$\begin{array}{c}\text { Table } 2 \\
\text { Influence of Diode laser treatment on seed } \\
\text { germination }\end{array}$} \\
\hline \multirow[t]{3}{*}{ Treatments } & \multicolumn{6}{|c|}{$\%$ of seeds } \\
\hline & \multicolumn{2}{|c|}{$\begin{array}{l}\text { Germinated } \\
\text { normally }\end{array}$} & \multicolumn{2}{|c|}{$\begin{array}{l}\text { Germinated } \\
\text { abnormally }\end{array}$} & \multicolumn{2}{|c|}{$\begin{array}{c}\text { Non } \\
\text { germinated } \\
\text { seeds }\end{array}$} \\
\hline & dry & wet & dry & wet & dry & wet \\
\hline Control & 70 & 80 & 15 & 16 & 15 & 4 \\
\hline D1 & 83 & 87 & 7 & 5 & 10 & 8 \\
\hline D2 & 82 & 93 & 8 & 2 & 10 & 5 \\
\hline D3 & 63 & 79 & 4 & 5 & 33 & 16 \\
\hline D4 & 40 & 50 & 10 & 3 & 50 & 47 \\
\hline
\end{tabular}

Generally $\mathrm{He}-\mathrm{Ne}$ and diode laser enhanced the germination percentage of wheat cultivars after two days a maximum of $95 \%$ after irradiation with $\mathrm{He}-\mathrm{Ne}$ for $5 \mathrm{~min}$ in wet condition , and $93 \%$ after irradiation by diode laser for $5 \mathrm{~min}$. Generally He-Ne \& diode laser enhanced the germination percentage of wheat cultivars after two days a maximum of $95 \%$ \& $93 \%$ after irradiation respectively for 5 minutes in respect to control, with the beginning to infection with fungus in both irradiated and non irradiated seeds .An irradiation of 10 minutes showed no significant effect on germination percentage, while irradiation of 15 minutes caused a general inhibition in germination percentage in the two conditions (dry \& wet) with maximum germination percentage $10 \%$ recorder and highly infection. Table 3 showed the effect of SHG Nd-YAG laser of the germination percentage normally and abnormally as well as non germinated seed in comparison to control in dry \& wet condition

\begin{tabular}{|c|c|c|c|c|c|c|}
\hline \multicolumn{7}{|c|}{ Table 3 } \\
Influence of SHG Nd-YAG laser treatment on seed \\
germation \\
\hline Treatments & \multicolumn{5}{|c|}{$\%$ of seeds } \\
\cline { 2 - 7 } & $\begin{array}{c}\text { Germinated } \\
\text { normally }\end{array}$ & $\begin{array}{c}\text { Germinated } \\
\text { abnormally }\end{array}$ & \multicolumn{2}{c|}{$\begin{array}{c}\text { Non } \\
\text { germinated } \\
\text { seeds }\end{array}$} \\
\cline { 2 - 7 } & dry & wet & dry & wet & Dry & wet \\
\hline Control & 70 & 80 & 15 & 16 & 15 & 4 \\
\hline d1 & 78 & 82 & 7 & 5 & 15 & 13 \\
\hline d2 & 85 & 93 & 6 & 2 & 9 & 5 \\
\hline d3 & 60 & 71 & 5 & 7 & 35 & 22 \\
\hline d4 & 35 & 50 & 15 & 3 & 50 & 47 \\
\hline
\end{tabular}

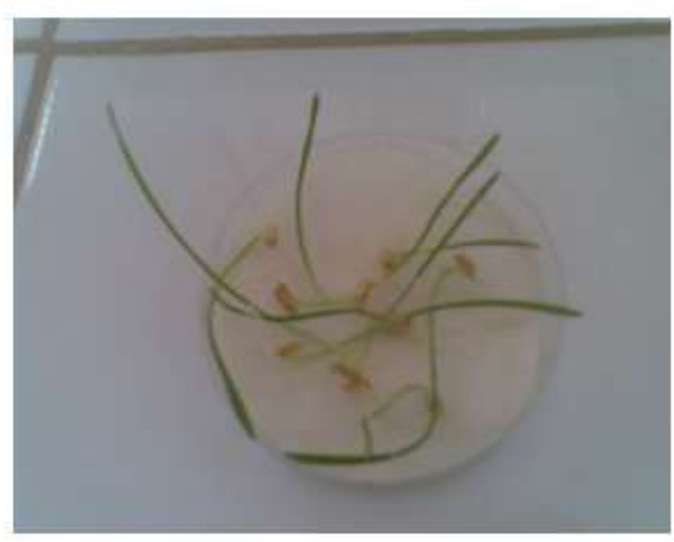

Fig.2 Seeds irradiated with SHG Nd-YAG after 3 days

Generally, SHG Nd-YAG laser significantly enhanced the germination percentage of wheat after 3 days to reach maximum of $93 \%$ after irradiation. For the percentage of non germinated seeds there were no important variations. On the other hand, there were high significant differences in resistant to fungi infection among the three types .Seeds irradiated with SHG Nd-YAG laser, no fungi infection was recorded Fig.2, while seeds irradiated by the two other types show highly infection especially after 3 days Fig.3, and the Petri plates which added to them antifungal agent show significant increase in infection with and without irradiation Fig4. 


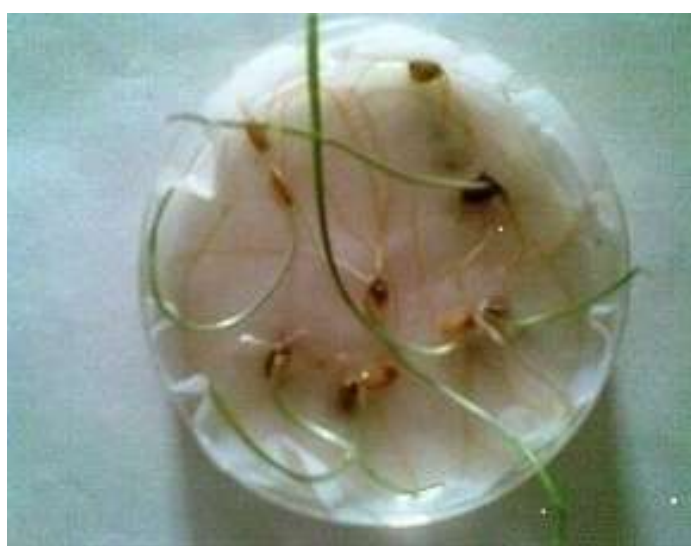

Fig.3Highly infected seeds after 3 days irradiation with Diode laser

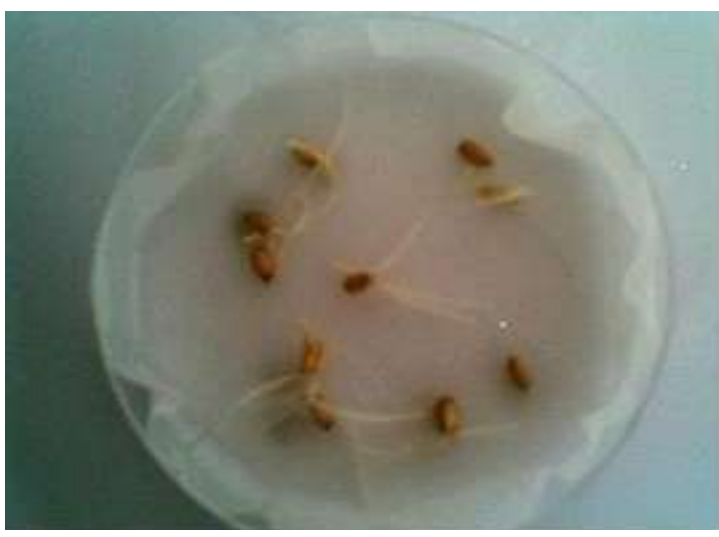

Fig.4 Petri plates with antifungal agent, after three days

\section{Discussion:}

Exposing the hard wheat seeds to laser irradiation from He-Ne and Diode lasers led to a considerable improvement in the growth and early development of the plant, while laser radiation produced by second harmonic generation Nd-YAG laser with wavelength $532 \mathrm{~nm}$ modifies the germination velocity of growth and resistant to fungal infection of hard wheat seeds when treated in wet condition . The effects of laser treatment on plant growth still require proper explanation .they may be the result of bioenergetics structural excitement causing cell pumping and enzymatic stimulation. It is well known, there are many enzymes that control the plant growth and development so The basis of this mechanism might be the existence of phytochrome which are sensory photoreceptors that regulate growth and development of plants in the response to light stimuli .These phytochroms not only in plants and seeds but also some viruses, bacteria and fungi[26][27][28][29].The absorption spectrum of these photoreceptors is in the visible and infrared light [30][31][32][33], upon absorption of this light ,phytochrome becomes active .this induce a cascade of enzymatic reactions that lead to seed germination and flowering [34] this is analogous to actions that occur within human tissue. In the present study , laser irradiation by second harmonic generation Nd-YAG, was seen as an alternative for the control of diseases originating in the seed, on the other hand using irradiation with He-Ne laser and Diode laser cause a more intense development of fungi as compared to the control. Other authors have reported the effects of laser irradiation on growth and development of bacteria as Escherichia coli, Irradiation of the bacteria E. coli with a He-Ne laser $(632.8 \mathrm{~nm})$ within a range of values produced two maximum values in the growth stimulation before reaching a minimum value, after which the growth was observed [35]. On the other hand, in fungi[22] reported that laser irradiation of soybean seeds for 3 min caused a clear reduction in the number of seed-borne fungi which became more pronounced when the irradiation time was extended using a laser of He-Ne with $\lambda=$ $632.8 \mathrm{~nm}$ and power of $7.3 \mathrm{~mW}$. The production of alkaline protease, blood heamolysis, pyocyanine and MICs values of (amikacin and piperacillin) were reduced significantly by irradiation with red light from $2 \mathrm{~W}$ diode laser with $805 \mathrm{~nm}$ wavelength and power density $7.07 \mathrm{~W} / \mathrm{cm}^{2}$ with respect to both light energy dose and exposure times in Pseudomonas aeruginosa [36]. In invitro study, complete eradication of methicillin-resistant, Staphylococcus aureus was achieved following 15 minute exposure to a $632.8 \mathrm{~nm} \mathrm{He}-\mathrm{Ne}$ laser in the presence of toluidin blue $\mathrm{O}$ photosensitizer [37].seeds that were treated with laser pre sowing have to absorb more energy than the non treated ones, as laser broke the kinetic equilibrium of germination seeds and enhanced internal energy of seeds. Consequently, metabolisms of the plants pretreated with laser were accelerated [38].

\section{Conclusion :}

In conclusion fungal infection cereals in general and hard wheat in particular is a cause of cute concern ,as wheat is a major component of most diets of the world and fungal pathogens cause $10 \%$ yield loss worldwide. Development of new alternative therapeutic approach is necessary to curtail fungi infection. This in vitro study demonstrated that pre sowing exposure to SHG Nd-YAG laser in wet and dry condition was able to sterilize wheat seeds, improve its growth and development, and may be a good candidate for novel treatment of fungal infected wheat seeds.

\section{References}

[1] Soltani F., Kashi A., Arghavani M. Effect of magnetic field on Asparagus originalis L.Seed germination and seedling growth .Seed Science and Technology ,34(2),2006,349-353.

[2] Vasilevski G. Perspectives of the Application of Biophysical Methods in Sustainable Agriculture.BULG.J.PLANT PHYSIOL.,2003,179-186. 
[3] Aladjadjiyan A.The Use of Physical Methods for Plant Growth Stimulation in Bulgaria.Journal of Central European Agriculture ,8(3),2007,369-380.

[4] Injushin M,V.,Expertnes of bioenergetic structure-horizo of new opinion Voprosi Biogoloniki,Proceedings of papers,1990,314,Alma-Ata.

[5] Raven ,Peter H.,Ray F.Evert,Susan E.Eichhorn(2005).Biology of plants, $7^{\text {th }}$ Edition .(New York:W.H.Freeman and Company Publishers,2005).pp.504-508.ISBN 0-7167-1007-2.

[6] Muszynski S.,and Gladyszewska B.Representation of He-Ne laser irradiation effect on radish seeds with selected germination indices.International Agrophysics, 22,2008,151-157.

[7] Jiang, X.L., A preliminary experimental report on killing pests by laser. (Liangsh; zhuzang Hubifood school, wuhan, china. 4, 1981), 33-36

[8] Dinoev St.,Antonov M.,Stoyanov T.,Gerogieva Chr. Spectral impact of low-power laser radiation on wheat and maize parameters.Bulgarian Academy of Sciences ,2004,54.

[9] Shinomura T. Phytochrome regulation of seed germination. J. Plant Res., 110(1),1997, 151-161.

[10] Hartmann K.M. and Mollwo A, The action spectrum for maximal photosensitivity of germination. Natur wissenschaften, 87, 2000,398-403.

[11] Durkova E . The activity of wheat grains and the effect of laser radiation. Acta Phytotech., 49,1993,59-66.

[12] Gładyszewska B . Pre-sowing laser biostimulation of cereal grains. Tech. Sci., 6,2006,33-38

[13] Hernandez AC, Carballo C A, Cruz-Orea A, Ivanov R, E. San Martin, Michtchenko . Photoacoustic Spectroscopy Applied to the Study of the Influence of Laser Irradiation on Corn Seeds. J. Physique IV (France), 125, 2005, 853-855.

[14] Hernández AC, Carballo CA, Artola A, Michtchenko A . Laser irradiation effects on maize seed field performance. Seed Sci.Technol., 34,2006, 193-197.

[15] Hernandez AC, Carballo CA, Michtchenko A, and Lopez BJ .Pretreatment laser light on maize seed vigor. Int. E-journal Eng. Mathematics: Theory Appl., 1,2007, 87-94.

[16] Hernandez AC, Carballo CA, Cruz-Orea, Ivanov R, Domínguez PF. The carotenoid content in seedlings of maize seeds irradiated by a $650 \mathrm{~nm}$ diode laser: Qualitative photoacoustic study. Eur. Phys. J. Spec. Topics, 153, 2008a, 515-518.

[17] Hernandez AC, Domínguez PA, Cruz-Orea A, Ivanov R, Carballo CA,Zepeda BR, Galindo SL . Laser irradiation effects on field performance of maize seed genotypes. Int. Agrophys., 23,2009b,327-332.

[18] Hernandez AC, Dominguez PA, Cruz- Orea A, Ivanov R, Carballo CA,Zepeda BR . Laser in agriculture (Review). Int. Agrophys., $24,2010,407-422$.

[19] Tobgy KMK, Osman YAH, Sherbini SA . Effect of laser radiation on growth, yield and chemical constituents of anise and cumin plants. J. Appl. Sci. Res., 5,2009, 522-528.

[20] Oerke EC . Centenary review, crop losses to pests. J. Agric. Sci.,144,2006, 31-43.

[21] Bel'skii AI, Mazulenko NN. Effects of presowing treatment of barley seeds on the incidence of fungal diseases on the plants. Mikologiya i Fitopatologiya, 18,1984, 312-31

[22] Ouf SA, Abdel-Hady NF . Influence of He-Ne Laser Irradiation of Soybean seeds on seed myclofora, growth, nodulation, and resistance to Fusarium solani. Folia Microbiol., 44,1999,388-396

[23] Wilczek M, Koper R, Cwintal M, Kornillowicz-Kowalska T. Germination capacity and health status of alfalfa seeds after laser treatment. Int. Agrophys., 19,2005a,85-89.

[24] Wilczek M, Koper R, Ćwintal M, Korniłłowicz- Kowalska T . Germination capacity and health status of hybrid alfalfa seeds after laser treatment. Int. Agrophys., 19,2005b,257-261.

[25] Nenadic K, Franjo J, Stjepan P . An Investigation of Automatic Treatment of Seeds with Low Power Laser Beam. Automatika, 49,2008,127-13

[26] Lamparter T . Evolution of cyanobacterial and plant phytochromes. FEBS Lett.,2004,573: 1-5

[27] Levskaya A, Chevalier AA, Tabor JJ, Simpson ZB, Lavery LA, Levy M, Davidson EA, Scouras A, Ellington, Levskaya AD, Weiner OD, Lim WA, Voigt CA . Spatiotemporal control of cell signalling using a light-switchable protein interaction. Nature, 461,2009,997-1001.

[28] Mathews S, Burleigh JG, Donoghue MJ . Adaptive evolution in the photosensory domain of phytochrome a in early angiosperms. Mol. Biol. Evol., 20,2003, 1087-1097

[29] Li Xu, Yang YJ, LI Y. Protein identification and mRNA analysis of phytochrome-regulated genes in Arabidopsis under red light. Science China Series C: Life Sci., 52,2009,371-380 .

[30] Smith H .Phytochromes and light signal perception by plants an emerging synthesis. Nature, 407,2000, 585-591

[31] Quail PH . Phytochrome photosensory signalling networks. Nature Reviews Mol. Cell Biol., 3,2002,85-93.

[32] Shimizu-Sato S, Huq E, Tepperman J M, Quail P H . A lightswitchable gene promoter system. Nat. Biotechnol., 20,2002,10411044.

[33] Casal JJ, Yanosvsky MJ. Regulation of gene expression by light. Int. J. Dev. Biol., 49, 2005, 501-511

[34] Karu T, Tiphlova O, Esenaliev R, Letokhov V. Two diferents mechanisms of low intensity laser photobiological effects on Escherichia Coli. J. Photochem. Photobiol. B: Biol., 24,1994, 155-161.

[35] Karu, T. Low-power laser therapy. In: (Biomedical Photonics Handbook (T. VoDinh, ed.) CRC Press, Boca Raton, FL, 48, 2003)pp. 1-25.

[36] Rassam Y.Z. The Effect of Laser Light on Virulence Factors and Antibiotic Susceptibility of Locally Isolated Pseudomonas Aeruginosa . Journal of Applied Sciences Research, 6(8),2010, 1298-1302.

[37] Hajim, K., D. Saad, Y. Rassam, Laser light combined with a photosensitizer may eliminate methicillin-resistant strains of Staphylococcus aureus. Lasers Med. Sci., 25(5),2010, 743-748

[38] Abu-Elsaoud A.M., Tuleukhanov S.T. and Abdel-Kader D.Z.(2008). Effect of Infra-Red Laser on Wheat (Triticum aestivum) Germination. International Journal of Agricultural Research, 3(6), 2008, 433-438. DOI: 10.3923/ijar.2008.433.4. 